\title{
ASPEK PIDANA DI ATAS KERETA REL LISTRIK/DIESEL REGULER (EKONOMI) DALAM WILAYAH JABODETABEK
}

\author{
I. Sriyanto ${ }^{1}$
}

\begin{abstract}
A mode of public transportation that has become increasingly popular for the people of JABODETABEK is the Electric Train and the Diesel Train (KRL and KRD). This is proven through daily observation particularly during office days and certain times when many passengers cram areas that are not originally designed for them, i.e. on top of train coaches, as not all of them can fit in the train coaches. If such an incident is only perceived from the economic perspective (the financial income from the purchase of the ticket fares by the many passengers), of course the income will be quite significant for PT Kereta Api Indonesia. Unfortunately, the overflowing condition of train passengers is used by some passengers to not purchase ticket fares based on the following speculations: (a) there will not be a ticket inspection as the passengers are overcrowded, so the conductor will feel reluctant to find a way to get through the passengers when it is even impossible to move; (b) even if there is a ticket inspection on the train, the passengers who do not purchase a ticket can directly pay the conductor with an amount of money that is less in value or of same value to the fare of the ticket sold in the ticket booths. In general, the conductors will receive these direct payments, thus the issue becomes resolved. The conspiration between the train passengers and the KRL/KRD conductor will become the basis of analysis from the standpoint of the Criminal Law.
\end{abstract}

Keywords: KRL/KRD, tickets, fines, criminal law

\begin{abstract}
Abstrak
Moda transportasi umum yang sangat popular bagi warga JABODETABEK untuk bepergian adalah Kereta Rel Listrik dan Kereta Rel Diesel (KRL dan KRD). Hal tersebut terbukti melalui pemandangan kita sehari-hari terutama pada hari kerja dan pada saat-saat tertentu, banyaknya penumpang sampai memadati pula tempat yang bukan semestinya diperuntukkan bagi penumpang kereta bersangkutan, yaitu di
\end{abstract}

1 Dosen Tetap pada Fakultas Hukum Universitas Indonesia. Alamat kontak: i_sriyanto@yahoo.co.id 
atas gerbong kereta karena mereka tidak dapat tertampung seluruhnya di dalam gerbong kereta bersangkutan. Apabila hal tersebut hanya dilihat melalui segi ekonomi (pemasukkan uang dari hasil pembelian tiket oleh para penumpang yang sedemian padat tersebut) maka tentunya akan menghasilan pemasukan uang yang cukup berarti bagi PT Kereta Api Indonesia. Sayangnya, ternyata bahwa padatnya penumpang tersebut justru dimanfaatkan oleh sebahagian dari para penumpang bersangkutan untuk tidak membeli tiket, dengan spekulasi: (a) tidak akan terdapat pemeriksaan tiket karena padatnya penumpang luar biasa, sehingga petugas pemeriksa tiket (kondektur) pun enggan bersusah payah untuk mencari jalan melewati para penumpang yang untuk bergerak saja sudah sangat sulit; (b) kalaupun ternyata terdapat pemeriksaan tiket di atas kereta, para penumpang yang tidak membeli tiket akan membayar secara langsung kepada kondektur dengan sejumlah uang yang biasanya nilai jumlah uang tersebut lebih kecil atau sama dengan harga tiket yang dijual pada loket penjualan. Para kondektur pun pada umumnya akan menerima pembayaran langsung yang tidak resmi itu, dan selesailah persoalan. Kerja sama antara penumpang dengan kondektur KRL/KRD inilah yang akan dianalisis berdasarkan perspektif hukum pidana.

Kata kunci: KRL/KRD, tiket, denda, hukum pidana

\section{Latar Belakang}

Kiranya sudah menjadi pengakuan umum bahwa Kereta Rel Listrik (yang selanjutnya disebut KRL) dan Kereta Rel Diesel (KRD) yang beroperasi di wilayah Jakarta, Bogor, Depok, Tangerang, dan Bekasi (JABODETABEK), merupakan jasa transportasi yang termurah dibandingkan dengan jasa transportasi lainnya yang ada di wilayah JABODETABEK. Demikian juga kiranya sudah bukan rahasia lagi bagi mereka yang sering mempergunakan jasa KRL/KRD tersebut, dengan leluasa tanpa membeli tiket KRL/KRD yang akan dinaiki, mereka dapat naik dan mengikuti perjalananan sesuai dengan rute KRL/KRD yang bersangkutan.

Harga tiket KRL/KRD untuk jarak yang paling dekat adalah Rp.1.000,- (satu ribu rupiah) sedangkan yang terjauh $\mathrm{Rp}$. 2.000,- (dua ribu rupiah). Di beberapa stasiun kereta, misalnya di Jakarta Kota, Gambir, dan Jatinegara, telah dipasang spanduk dengan tulisan yang besar-besar, yaitu:

Penumpang yang kedapatan tidak memiliki tiket kereta yang sedang dinaiki akan didenda untuk kereta jarak jauh sebesar 2 (dua) kali harga 
tiket, sedang untuk kereta wilayah JABODETABEK didenda sebesar 5 (lima) kali harga tiket yang sesuai untuk tujuan akhir dari penumpang bersangkutan. Semua denda tersebut harus dibayar tunai pada saat itu juga.

Apabila semua calon penumpang KRL/KRD itu menghiraukan pringatan yang tertulis dalam spanduk di atas, dan apabila tindakan denda sebagaimana diancamkan kepada para penumpang yang tidak memiliki tiket di dalam KRL/KRD yang bersangkutan itu benar-benar diterapkan, maka kiranya tidak akan timbul permasalahan hukum dalam operasionalisasi KRL/KRD wilayah JABODETABEK. Sayangnya sebahagian calon penumpang KRL/KRD itu tidak perduli dengan katakata peringatan dalam spanduk di atas. Mereka lebih suka memilih untuk tidak membeli tiket dan langsung naik ke KRL/KRD yang mereka kehendaki.

Apa yang mereka lakukan itu telah mereka sadari bahwa selama dalam perjalanan tidak akan timbul masalah yang berarti dengan kondektur KRL/KRD bersangkutan, apalagi bila KRL/KRD itu memuat penumpang yang sangat melebihi kapasitas, sehingga kondektur KRL/KRD tersebut biasanya tidak berminat lagi untuk memeriksa tiket para penumpang satu persatu, sementara ia harus berdesak-desakan dengan para penumpang yang benar-benar sangat padat. Dengan demikian hari itu mereka beruntung, dengan tanpa membeli tiket mereka dapat naik KRL/KRD dan sampai ke tempat tujuan. Apabila kebetulan memang terjadi pemeriksaan oleh kondektur, merekapun dengan mudah dan cepat dapat menyelesaikan persoalannya. Mereka yang tidak memiliki tiket KRL/KRD menyampaikan uang sebesar Rp.1.000,- (satu ribu rupiah) kepada kondektur yang kebetulan memeriksanya, maka urusanpun menjadi beres. Kondektur KRL/KRD bersangkutan juga tidak menanyakan apapun kepada mereka, misalnya naik dari mana, turun di mana dan sebagainya. Banyak pula di antara para penumpang yang tidak memiliki tiket akan mengatakan kepada kondektur KRL/KRD bersangkutan dengan menyatakan bahwa mereka ABU yang maksudnya adalah Abudemen. Biasanya kondektur juga enggan untuk meminta bukti bahwa mereka memang penumpang yang memiliki Kartu Abudemen (Kartu ABU). ${ }^{2}$

Dalam melakukan perjalanan dengan kereta rel, biasanya setiap orang akan mengalami 3 (tiga) kali pemeriksaan oleh petugas Perseroan Terbatas Kereta Api Indonesia (PT. KAI) yang sedang bertugas sebagai pemeriksa tiket kereta rel

\footnotetext{
${ }^{2}$ Pengamatan langsung, di mana sampai saat ini Penulis sangat sering mempergunakan jasa $\mathrm{KRL/KRD} \mathrm{untuk} \mathrm{melakukan} \mathrm{perjalanan} \mathrm{dalam} \mathrm{wilayah} \mathrm{JABOTABEK.}$
} 
bersangkutan. Petugas pemeriksa tiket tersebut akan terdiri 3 (tiga) bagian, pertama yaitu petugas pemeriksa kepemilikan tiket/Kartu ABU setiap orang yang akan mempergunakan jasa kereta rel. Petugas bersangkutan akan berada di pintu masuk peron stasiun kereta rel. Kedua adalah kondektur, yaitu petugas yang berada di dalam kereta rel, untuk memeriksa ulang atas kepemilikian tiket ataupun Kartu ABU setiap penumpang kereta rel bersangkutan. Ketiga, petugas yang berada di pintu keluar peron stasiun, bertugas mengambil kembali tiket/memeriksa kepemilikan kartu ABU setiap penumpang kereta rel yang turun di stasiun kereta rel bersangkutan.

Apabila mekanisme tahapan untuk mempergunakan jasa kereta rel itu dilakukan sebagimana diuraikan di atas, baik oleh setiap penumpang maupun oleh petugas PT. KAI, kiranya tidak akan menimbulkan permasalahan hukum yang perlu diangakat dalam suatu tulisan, namun ternyata mekanisme tersebut tidak berjalan sebagaimana mestinya.

Sebagaimana telah dikemukakan di atas, bahwa para penumpang yang tidak memiliki tiket kereta rel bersangkutan, biasanya malakukan "perdamaian" secara diam-diam dengan kondektur, yaitu dengan menyampaikan uang sebesar Rp.1.000,(satu ribu rupiah) kepada kondektur bersangkutan, urusannya menjadi selesai dengan sendirinya. Di pintu masuk peron stasiun ataupun pintu keluar dari peron stasiun, tampaknya para petugas PT. KAI juga enggan untuk secara tegas meminta kepada setiap calon penumpang ataupun penumpang yang turun dari kereta rel dan keluar dari peron, untuk menunjukkan kepemilikan tiket kereta bersangkutan ataupun Kartu ABU. Kemudahan lain yang dapat dimanfaatkan oleh sebagian calon penumpang untuk tidak membeli tiket, adalah ternyata tidak semua stasiun kereta rel JABODETABEK itu memiliki pos pemeriksaan tiket bagi calon penumpang ataupun penumpang yang turun dan keluar dari peron.

Permasalahan yang timbul dari kejadian sebagaimana telah dikemukakan, kiranya akan merupakan permasalahan yang sangat luas, yaitu menyangkut besarnya uang yang diperkirakan seharusnya dapat masuk ke pihak PT. KAI apabila setiap penumpang itu membeli tiket. Demikian pula kemungkinannya terdapat kerugian materiel bagi pihak PT. KAI atas perilaku para penumpang dan petuganya tersebut. Permasalahan berikutnya adalah menyangkut latar belakang mengenai perilaku para penumpang dan petugas PT. KAI wilayah JABODETABEK, dan lebih luas lagi menyangkut mengenai kebijakan PT. KAI sebagai lembaga yang mengoperasikan KRL dan KRD JABODETABEK dan Departemen Perhubungan (DEPHUB) sebagai lembaga yang membawahi PT. KAI. Dalam penulisan ini akan diteliti pula mengenai kemungkinan terjadinya suatu "penyertaan tindak pidana" (deelneming) dalam perbuatan yang dilakukan oleh para penumpang dengan para petugas PT. KAI bersangkutan. 


\section{Pembahasan}

Dalam membahas permasalahan ini, dimulai dengan mengajukan tiga pertanyaan berikut:

1. Apakah perbuatan yang dilakukan oleh sebagian penumpang yang tidak memilki tiket KRL/KRD dengan menyampaikan uang sebesar Rp.1.000,(satu ribu rupiah) setiap orang kepada kondektur KRL/KRD itu dapat dikualifikasikan sebagai tindak pidana "penyuapan" sebagaimana dirumuskan dalam Pasal 209 Kitab Undang-Undang Hukum Pidana (KUHP)?

2. Apakah perbuatan kondektur KRL/KRD yang menerima uang sebesar Rp.1.000,- (satu ribu rupiah) dari beberapa penumpang yang tidak memiliki tiket tersebut dapat dikualifikasikan sebagai tindak pidana ("Kejahatan yang dilakukan dalam jabatan), khususnya sebagaimana dirumuskan dalam Pasal 218 atau 219 KUHP, yaitu mengenai "penerimaan suap"?

3. Apakah terdapat kemungkinannya terjadi "penyertaan tindak pidana" antara sebagian penumpang yang telah menyampaikan uang kepada kondektur dengan kondektur KRL/KRD itu sendiri dan juga dengan petugas PT. KAI yang lain?

Untuk mendapatkan jawaban dari tiga pertanyaan di atas, dalam pembahasan ini akan dikaji (dianalisis) melalui pendekatan beberapa teori:

1. Teori dalam Hukum Pidana, untuk menentukan bilamana suatu perbuatan termasuk dalam tindak pidana; dan bilamana suatu tindak pidana tersebut sebagai "tindak pidana suap";

2. Teori mengenai Tindak-Tindak Pidana Tertentu Dalam KUHP (khususnya mengenai "kejahatan yang dilakukan dalam jabatan"), yang akan dianalisis berdasarkan beberapa ketentuan perundang-undangan yang terkait.

3. Teori mengenai "penyertaan tindak pidana" baik yang ditulis oleh para sarjana hukum berkebangsaan Belanda maupun Indonesia.

4. Teori mengenai Gabungan Tindak Pidana khususnya dalam kaitannya dengan ketentuan sebagaimana dirumuskan dalam Pasal 63, 64, dan 65 KUHP.

Ad.1. Teori mengenai Hukum Pidana

Dalam doktin mengenai teori hukum pidana pada umumnya diajarkan bahwa suatu perbuatan dapat dianggap sebagai tindak pidana apabila perbuatan tersebut memenuhi unsur-unsur: ${ }^{3}$ (a) Perbuatan melawan hukum; (b) Terdapatnya 
kesalahan; dan (c) Perbuatan tersebut dapat dipertanggungjawabkan kepada pelakunya.

Telah dianut suatu pengertian (khususnya Indonesia), bahwa "perbuatan melawan hokum" menurut hukum pidana adalah suatu perbuatan yang di samping melanggar hukum secara "formil", harus pula melawan hukum secara "materil". 4 Melawan hukum secara formil maksudnya adalah suatu perbuatan, dituliskan dalam suatu perumusan undang-undang bahwa perbuatan bersangkutan merupakan perbautan yang melanggar ketentuan tertulis tersebut). Sedangkan pengertian perbuatan melawan hukum secara mareril (materiele wederrechtelijkheid) adalah suatu prbuatan yang melawan asas-asas hukum umum (algemene beginselen van recht). ${ }^{5}$

Berkaitan dengan perbuatan para penumpang KRL/KRD yang menaiki kereta tersebut tanpa membeli tiket pada loket penjualan tiket, bukanlah merupakan suatu perbuatan yang termasuk tindak pidana dalam KUHP ataupun dalam ketentuan hukum pidana lainnya. Perbuatan para penumpang itu hanya melanggar ketentuan sebagaimana tertulis dalam spanduk yang dipasang pada beberapa stasiun tersebut. Pelanggaran atas ketentuan sebagaimana tertulis pada spanduk tersebut hanya akan dikenakan sanksi administratif, yaitu dengan melakukan pembayaran lima kali harga tiket sesuai dengan tujuan para penumpang masing-masing. Setelah dibayar denda administratif tersebut, permasalahan dianggap selesai, tidak terdapat suatu perkara apapun.

Berbeda halnya apabila kemudian para penumpang KRL/KRD itu membayar langsung kepada petugas pemeriksa tiket (kondektur) di atas kereta dengan jumlah uang yang sama besarnya dengan harga tiket yang dijual pada loket penjualan, atau bahkan membayar dengan jumlah uang yang lebih kecil dari harga tiket yang dijual pada loket penjualan, dengan maksud agar petugas tidak menjatuhkan sanksi pembayaran denda administratif. Tidak jarang pula para penumpang yang mengatakan pada kondektur bahwa ia adalah penumpang abudemen, akan tetapi tanpa menunjukkan kartu abodemen-nya (cukup dengan mengucapkan $\mathrm{ABU}$ ) kepada kondektur bersangkutan.

\footnotetext{
${ }^{3}$ E. Utrecht, "Hukum Pidana I", (Jakarta: Penerbitan Universitas, 1958), hal. 251-152.

${ }^{4}$ Vos dalam E. Utrecht, Ibid., hal. 267.

5 Ibid. Lihat pula J.E. Jonkers, "Hukum Pidana Hindia Belanda (Handboek van het Nederlandsch-Indische Strafrecht)", diterjemahkan oleh Tim Penerjemah Bina Aksara, Cetakan 1,
} (Jakarta: Bina Aksara, 1987), hal. 101. 
Bagi para penumpang KRL/KRD yang membayar langsung kepada kondektur di atas kereta dengan jumlah uang yang tidak sesuai dengan ketentuan administrasi (harus membayar sebesar lima kali harga tiket sesuai tujuan), dengan maksud agar petugas bersangkutan tidak menjatuhkan sanksi pembayaran denda administrasi tersebut, jelas terdapat ketentuannya dalam Pasal 209 KUHP, Pasal 2 UU No.11 Tahun 1980 Tentang Suap, ${ }^{6}$ dan Pasal 5 ayat (1) huruf b UU No.20 Tahun 2001 Tentang Perubahan Atas UU No.31 Tahun 1999 Tentang Pemberantasan Tindak Pidana Korupsi. ${ }^{7}$

Dalam penulisan ini tidak akan dibahas secara terperinci mengenai: (a) Siapa saja yang termasuk dalam lingkup sebagai Pegawai Negeri (lihat Pasal 92 KUHP); dan (b) Lamanya sanksi pidana bagi masing-masing peserta dalam perbuatan antara penumpang dengan kondektur (lihat masing-masing pasal dalam UU yang terkait). Dalam hal ini yang jelas adalah bahwa perbuatan masingmasing (penumpang dan kondektur) tersebut telah memenuhi perumusan salah satu dari beberapa ketentuan pidana tertulis sebagaimana dikemukakan di atas. Dengan demikian baik perbuatan penumpang maupun perbuatan kondektur bersangkutan, telah memenuhi unsur melawan hukum yang bersifat formil (ketentuan hukum yang tertulis).

Kemudian apakah perbuatan para penumpang dan kondektur bersangkutan juga termasuk dalam melawan hukum yang bersifat materil (materile wederrechtelijkheid)? Pengertian materiele wederrechtelijheid sebenarnya adalah sama dengan pengertian onrechtmatige daad dalam bidang Hukum Perdata. ${ }^{8}$ Adapun Onrechtmatige daad yaitu:

${ }^{6}$ H. Oemar Seno Adji, "Herziening Ganti Rugi Suap Perkembangan Delik", (Jakarta: Erlangga, 1981), hal. 208: Perbedaannya dengan ketentuan baik dalam Pasal 209 KUHP maupun Pasal 5 ayat (1) huruf b UU No.20 Tahun 2001 adalah bahwa ketentuan dalam Pasal 2 UU No.11 Tahun 1980 tidak membatasi bahwa yang terlibat dalam perbuatan suap harus terkait dengan pegawai negeri.

${ }^{7}$ Apabila penerima suap adalah seorang pegawai negeri, maka berlakulah Pasal 209 KUHP bagi penyuap dan Pasal 418-420 KUHP bagi penerima suap, sebagaimana telah ditingkatkan menjadi tindak pidana Korupsi sebagaimana dirumuskan dalam Pasal 5 ayat (1) huruf b UU No.20 Tahun 2001 bagi penyuap, dan Pasal 5 ayat (2) UU No.20 Tahun 2001 bagi penerima suap. Dalam hal ini akan berlaku sesuai dengan adagium yang menyatakan bahwa lex spesialis derogate legi generali.

8 Pompe dalam Indriyanto Seno Adji, "Korupsi Kebijakan Aparatur Negara \& Hukum Pidana", Cetakan 2, (Jakarta: Diadit Media, 2007), hal. 29-30. 
Tidak saja perbuaan-perbuatan yang memperkosa hukum dari hakhak subyektif orang lain dan bertentangan dengan kewajiban hukum dari pelaku, tetapi juga perbuatan-perbuatan yang bertentangan dengan tata kesopanan dan yang bertentangan dengan kepntusan yang harus dihindarkan dalam pergaulam masyarakat. ${ }^{9}$

Mahkamah Agung Belanda (Hoge Raad) memberikan pengertian mengenai onrechtmatige daad adalah: ${ }^{10}$

Dengan suatu perbuatan melanggar hukum diartikan setiap perbuatan atau kelalaian yang menimbulkan pelanggaran terhadap hak orang lain atau bertentangan dengan kewajiban hukum pelaku atau kesusilaan yang baik dan kepatutan yang ada dalam masyarakat.

Berkatian dengan perbuatan para penumpang dan kondektur bersangkutan, di mana mereka menjalin saling pengertian untuk saling menguntungkan di antara pribadi masing-masing. Dalam hal ini para penumpang sengaja mengabaikan kewajibannya untuk membeli tiket sebelum menaiki kereta, dengan spekulasi apabila terdapat pemeriksaan tiket di atas kereta mereka akan membayar kepada kondektur dengan harga di bawah harga tiket resmi yang dijual pada loket penjualan tiket. Apabila ternyata di atas kereta tidak terdapat pemeriksaan tiket karena sangat padatnya penumpang, maka mereke (para penumpang tersebut akan merasa lebih beruntung lagi. Sedangkan kondektur juga mendapat keuntungan dari pembayaran langsung oleh para penumpang dengan tanpa harus berselisih dengan para penumpang tanpa tiket yang sekian banyaknya itu.

Apabila dilihat dari besarnya jumlah uang yang dibayarkan oleh masingmasing penumpang kepada kondektur bersangkutan (yang hanya berkisar antara satu ribu atau dua ribu rupiah), tampaknya perbuatan tersebut tidak patut untuk dipermasalahkan. Akan tetapi apabila uang tersebut dibayarkan oleh sejumlah penumpang tanpa tiket yang sedemikian banyaknya, kiranya dapat dibayangkan mengenai banyaknya jumlah uang yang terkumpul dari para penumpang bersangkutan. Bagi kondektur yang menerima uang dari para penumpang tanpa

\footnotetext{
${ }^{9}$ Satochid Kartanegara dalam Indriyanto Seno Adji, Ibid., hal.29.
}

${ }^{10}$ Algra, N.E. \& K. van Duyvendijk dalam Idriyanto Seno Adji, Ibid., hal. 33. Lihat pula Rosa Agustina, "Perbuatan Melawan Hukum", Cetakan 1, (Jakarta: Program Pascasarjana FH-UI, 2003), hal. 41-42. 
tiket yang sedemikian banyak, sedangkan ia bertugas di atas kereta tersebut dalam perjalanan bolak-balik beberapa kali dalam satu hari, maka kiranya dapat pula dibayangkan seberapa besar kondektur bersangkutan memperoleh penghasilan tambahan dalam suatu waktu tertentu, melalui kerja samanya dengan para penumpang kereta itu.

Pada gilirannya, perbuatan para penumpang dan para kondektur tersebut jelas akan dapat merugikan pihak PT. KAI bagi usaha pengelolaan operasional KRL/KRD, khususnya di wilayah JABODETABEK. Perbuatan para penumpang dan para kondektur tersebut jelas tidak mencerminkan "kepatutan" untuk dilakukan dalam suatu kehidupan bermasyarakat. Dengan demikian maka perbuatan para penumpang dan para kondektur tersebut telah memenuhi pula perbuatan melawan hukum yang bersifat materil (materiele wederrechtelijkheid ataupun onrechtmatige daad).

Pada uarian sebelumnya telah terbukti bahwa perbuatan para penumpang dan para kondektur tersebut memenuhi kriteria sebagai perbuatan melawan hukum dalam sifat formil. Ternyata perbuatan itu juga memenuhi kriteria sebagai perbuatan melawan hukum dalam sifat materil. Dengan demikian maka perbuatan para penumpang dan para kondektur tersebut adalah termasuk sebagai perbuatan melawan hukum dalam pengertian Hukum Pidana.

Dalam hukum pidana positif diterima secara umum adanya asas: geen straf zonder schuld (tiada hukuman tanpa kesalahan), di mana kesalahan berarti meliputi suatu perbuatan yang dilakukan secara "sengaja" ataupun karena "kelalaian"." Sedangkan "sengaja" dalam pengertian hukum pidana, menurut memori penjelasan atau Memorie van Toelichting (M.v.T.) harus meliputi dua aspek, yaitu willens en wetens (menghendaki dan mengetahui). Beberapa ahli hukum menganggap pengertian menurut M.v.T. mengenai "sengaja" tersebut tidak tepat, karena seseorang yang "menghendaki" melakukan sesuatu perbuatan belum tentu "mengetahui" secara pasti apa yang akan terjadi (akibat) dari perbuatannya tersebut. Dengan demikian, adalah cukup sebagai suatu "kesengajaan" apabila pelaku dapat membayangkan kemungkinan yang akan terjadi atas perbuatan yang telah dilakukannya. ${ }^{12}$

Berkaitan dengan perbuatan para penumpang yang membayar secara tidak resmi kepada kondektur, dan kondektur yang menerima pembayaran secara tidak

${ }^{11}$ Wirjono Prodjodikoro, "Asas-Asas Hukum Pidana di Indonesia", Cetakan 2, (Bandung: Eresco, 1979), hal. 64.

${ }^{12}$ E. Utrecht, Op.cit., hal.301 
resmi dari penumpang tersebut, keduanya adalah merupakan perbuantan yang memang mereka kehendaki, dengan tentunya mereka dapat membayangkan mengenai timbulnya kerugian pada pihak ketiga, yaitu pihak PT. KAI. Dengan demikian, baik perbuatan para penumpang maupun para kondektur tersebut telah memenuhi pula kriteria sebagai suatu perbuatan yang dilakukan secara "sengaja" dalam pengertian hukum pidana.

Unsur tindak pidana berikutnya adalah mengenai toerekeningsvatbaarheid (kemampuan bertanggungjawab.) ${ }^{13}$ dari pelaku. Dalam ketentuan hukum pidana mengenai ketidak-mampuan pelaku untuk dipertanggungjawabkan atas perbuatannya telah diatur dalam Pasal 44 KUHP dan UU No.3 Tahun 1997 Tentang Pengadilan Anak. Bagi pelaku yang termasuk dalam perumusan Pasal 44 KUHP, mengenai ketidak-mampuannya bertanggungjawab harus diputuskan oleh hakim. ${ }^{14}$ Sedangkan pelaku yang termasuk dalam perumusan UU No.3 Tahun 1997, di mana pada saat melakukan tindak pidana belum mencapai usia 18 tahun, apabila hakim menajtuhkan pidana penjara, maka lamanya pidana penjara adalah selama-lamanya (maksimal) seperdua dari pidana yang dijatuhkan kepada pelaku tindak pidana dewasa. Melalui pembahasan sebagaimana telah diuraikan, maka para penumpang di luar ketentuan Pasal 44 KUHP, adalah merupakan orangorang yang mampu dipertanggungjawabkan atas perbuatannya. Demikian pula para kondektur yang masih aktif dalam pekarjaannya, jelas juga merupakan orangorang yang mampu untuk dipertanggungjawabkan atas perbuatan mereka.

Dengan demikian maka baik para penumpang maupun para kondektur tersebut, perbuatan mereka adalah termasuk suatu "tindak pidana", di mana unsurunsur tindak pidana dalam perbuatan mereka terpenuhi, yaitu (a) Perbuatannya melawan hukum baik dalam sifat formil maupun materil; (b) Mereka memang sengaja untuk melakukan perbuatan, yaitu memberi dan menerima uang secara tidak resmi; dan (c) Mereka adalah orang-orang yang mampu bertanggungjawab atas perbuatannya.

Bagi penumpang yang mengatakan ABU kepada kondektur, pada hal sebenarnya penumpang bersangkutan tidak memiliki kartu abudemen, tidaklah terjadi suatu tindak pidana "penipuan" ("perbuatan curang" dalam Pasal 378

13 S. Wowasito, "Kamus Umum Belanda-Indonesia", (Jakarta: Ichtiar Baru-Van Hoeve, 1981), hal. 675: toerekeningsvatbaar = dapat dipertanggungjawabkan sepenuhnya atas perbuatannya. Lihat pula Sudarsono, "Kamus Hukum", Edisi Baru, Cetakan 5, (Jakarta: Rineka Cipta, 2007), hal. 503.

${ }^{14}$ R. Sugandhi, "KUHP Dan Penjelasannya", (Surabaya: Usaha Nasional, 1980), hal. 51. 
KUHP), sepanjang kondektur tersebut sebenarnya menyadari ataupun dapat menduga bahwa penumpang bersangkutan tidak memiliki kartu abudemen (berbohong), akan tetapi kondektur itu rela untuk membiarkan atau tidak mengambil tindakan apapun terhadap penumpang bersangkutan. Salah satu syarat untuk terjadinya suatu tindak pidana penipuan adalah apabila orang yang ditipu tersebut tidak menyadari bahwa ia ditipu ataupun dibohongi. ${ }^{15}$

\section{Ad. 2. Teori mengenai Tindak Pidana Tertentu (khususnya Kejahatatan dalam Jabatan)}

Sebagaimana telah dikemukakan bahwa apabila dilihat dari besarnya jumlah uang yang dibayarkan oleh masing-masing penumpang kepada kondektur bersangkutan (yang hanya berkisar antara satu ribu atau dua ribu rupiah), tampaknya perbuatan tersebut tidak patut untuk dipermasalahkan. Akan tetapi apabila uang tersebut dibayarkan oleh sejumlah penumpang tanpa tiket yang sedemikian banyaknya, kiranya dapat dibayangkan mengenai banyaknya jumlah uang yang terkumpul dari para penumpang bersangkutan. Bagi kondektur yang menerima uang dari para penumpang tanpa tiket yang sedemikian banyak, sedangkan ia bertugas di atas kereta tersebut dalam perjalanan bolak-balik beberapa kali dalam satu hari, maka kiranya dapat pula dibayangkan seberapa besar kondektur bersangkutan memperoleh penghasilan tambahan dalam suatu waktu tertentu, melalui kerja samanya dengan para penumpang kereta itu.

Apabila hanya dianalisis berdasarkan ketentuan Pasal 418 ataupun 419 KUHP dengan landasan pengertian bagi "pegawai negeri" pada Pasal 92 KUHP, maka kondektur ataupun pegawai PT. KAI pada umumnya, tidak termasuk dalam pengertian sebagai "pegawai negeri", karena PT. KAI adalah merupakan perusahaan swasta. Dengan demikian perbuatan kondektur tersebut tidak dapat dikatakan sebagai "kejahatan dalam jabatan", karena salah satu syaratnya adalah bahwa pelakunya harus sebagai Pegawai Negeri. Yurisprudensi telah memperluas cakupan mengenai pengertian dari pegawai negeri, akan tetapi hanya dengan menyebutkan bahwa Kepala Stasiun Jawatan Kereta Api saja yang termasuk di dalamnya, sedangkan para pegawai Jawatan Kereta Api lainnya tidak disebutkan. ${ }^{16}$

${ }^{15}$ H.A.K. Moch. Anwar (Dading), "Hukum Pidana Bagian Khusus (KUHP Buku II) Jilid 1", Cetakan 4, (Bandung: Alumni, 1986), hal. 42. Lihat pula S.R. Sianturi, "Tindak Pidana Di KUHP Berikut Uraiannya”, Cetakan 2, (Jakarta: Alumni AHAEM-PETEHAEM, 1989), hal. 636. 
Dalam Pasal 1 ayat (2) UU No. 31 Tahun 1999 Tentang Pemberantasan Tindak Pidana Korupsi disebutkan bahwa yang termasuk sebagai Pegawai Negeri salah satunya adalah orang yang menerima gaji atau upah dari suatu korporasi yang menerima bantuan dari negara atau daerah, ataupun orang yang menerima gaji atau upah dari korporasi yang mengunakan modal dan fasilitas dari negara atau masyarakat. Dengan demikian maka dapat disimpulkan bahwa pegawai PT. KAI adalah merupakan pegawai negeri.

\section{Ad.3. Teori mengenai Penyertaan Tindak Pidana}

Melihat bahwa perbuatan dari para penumpang dan kondektur, di mana unsur-unsurnya memenuhi beberapa pasal dalam beberapa ketentuan hukum pidana mengenai "suap" sebagaimana telah dikemukakan, maka dapat disimpulan pula bahwa perbuatan mereka adalah termasuk dalam tindak pidana suap. Adapun mengenai tindak pidana suap dalam teori hukum pidana adalah termasuk dalam "penyertaan tindak pidana yang bersifat khusus". Penyertaan tindak pidana dalam tindak pidana suap (termasuk yang diatur dalam Pasal 149 KUHP), dalam teori hukum pidana lazim pula disebut sebagai "penyertaan mutlak perlu" (noodzakelike deelneming). ${ }^{17}$

Penyertaan mutlak perlu (noodzakelijke deelneming) yaitu suatu tindak pidana yang dalam terjadinya tindak pidana tersebut sharus elalu melibatkan lebih dari satu orang. Dengan kata lain, suatu tindak pidana tidak akan terjadi apabila hanya dilakukan oleh satu orang. ${ }^{18}$ Dalam hal ini terdapat penyertaan yang masing-masing pelakunya diancam pidana yang sama beratnya (salah satu contohnya adalah tindak pidana perzinahan dalam Pasal 284 KUHP). Terdapat pula penyertaan yang masing-masing pelakunya dipidana dengan pidana yang berbeda beratnya, yaitu misalnya tindak pidana suap dalam Pasal 2 UU No.11

16 R. Soesilo, "KUHP Lengkap Dengan Komentar Pasal Demi Pasal", (Bogor: Politeia, 1996), halaman 100. Lihat pula kasus bank Duta dalam Komariah Emong Sapardjaja, “Ajaran Sifat Melawan Hukum Materiel Dalam Hukum Pidana Indoneia", Cetakan 1, (Bandung: Alumni, 2002), hal. 181.

Mengenai pengertian Jawatan, lihat Hasan Alwi dkk., "Kamus Besar Bahasa Indonesia", Edisi III, Cetakan 1, (Jakarta; Balai Pustaka, 2001), hal. 463: "Jawatan = bagian dari departemen atau pemerintah daerah yang mengurus (menyelenggarakan) suatu tugas atau pekerjaan yang luas lingkingannya". Dengan demikian Jawatan adalah merupakan Instansi Pemerintah.

\footnotetext{
${ }^{17}$ Wijono Prodjodikoro, Op. Cit., hal. 115.

${ }^{18}$ Ibid.
} 
Tahun 1980 (bagi penyuap) dan Pasal Pasal 2 UU No.11 UU.20 Tahun 1980 (bagi penerima suap).

Adapun penyertaan tindak pidana yang terjadinya tindak pidana tersebut harus selalu melibatkan pelaku lebih dari satu orang (yang biasanya tanpa korban), disebut pula sebagai "bentuk khusus dari penyertaan" (noodzakelijke vormen van deelneming). Dalam hal ini pada hakekatnya tindak pidana "suap" adalah merupakan suatu penyertaan tindak pidana juga, akan tetapi pertanggungjawaban dari masing-masing peserta tidak seperti yang termuat dalam ketentuan Pasal 55 KUHP (yaitu mengenai penyertaan tindak pidana pada umumnya). ${ }^{19}$

Dalam "penyertaan tindak pidana" sebagaimana dirumuskan dalam ketentuan Pasal 55 ayat (1) sub 1 KUHP, masing-masing pesertanya akan mendapatkan kualifikasi sebagai: a. Orang yang melakukan (pleger atau dader), b. Orang yang turut melakukan mede pleger), ataupun c. Orang yang menyuruh melakukan (doen pleger). Sementara itu ketentuan Pasal 55 ayat (1) sub 2 KUHP adalah merumuskan mengenai peserta dalam penyertaaan tindak pidana yang dikualifikasikan sebagai orang yang "membujuk" atau "menggerakkan" (uitlokker) kepada orang lain untuk melakukan suatu tindak pidana.

Dari berbagai kualifikasi bagi masing-masing peserta dalam penyertaan tindak pidana tersebut melahirkan beberapa sebutan mengenai bentuk dari penyertaan tindak pidana. Bentuk-bentuk penyertaan tindak pidana tersebut akan terdiri dari:

a. mededaders (penyertaan yang terdiri dari beberapa orang yang seluruhnya berkualitas sebagai orang yang melakukan tindak pidana, yaitu masingmasing peserta memenuhi semua unsur delik ), ${ }^{20}$

b. medeplegen (penyertaan dari beberapa orang yang tidak seluruh pesertanya berkualitas sebagai orang yang melakukan, artinya tidak semua peserta harus memenuhi semua unsur delik); ${ }^{21}$

${ }^{19}$ H. Loebby Loqman, "Percobaan, Penyertaan Dan Gabungan Tindak Pidana", Cetakan 1, (Jakarta: Universitas Tarumanegara, 1996), hal. 99:

20 P.A.F. Lamintang dan D. Simon, "Kitab Pelajaran Hukum Pidana, (Leerboek het Nedelandches Strafrecht)", Cetakan 1, (Bandung: Pionir Jaya, 1992), hal. 322.

${ }^{21}$ Ibid., hal. 324. Catatan: beberapa ahli hukum pidana mempersamakan pengertian antara mededaders dengan medepelegen., dan terdapat pula ahli hukum pidana yang menyatakan bahwa tidak terdapatnya bentuk mededaders, yang ada adalah bentuk medeplegen. 
c. doen plegen (penyertaan yang terjadi antara orang yang menyuruh dengan orang yang disuruh untuk melakukan suatu tindak pidana. Bentuk penyertaan tindak pidana ini hanya dapat terjadi apabila orang yang melakukan tindak pidana yang disebut sebagai orang yang disuruh itu adalah orang yang tidak dapat dipertanggungjawabkan secara hukum pidana, karena tidak adanya unsur kesengajaan dalam pengertian hokum pidana dari orang yang disuruh tersebut. Contohnya misalnya orang yang tidak tumbuh sehat jiwanya sebagaimana dirumuskan dalam ketentuan Pasal 44 KUHP, atau anak yang masih di bawah umur, baik dengan diberikan upah maupun tidak diberikan upah, diminta oleh orang lain yang sehat jiwanya untuk melakukan tindak pidana. $^{22}$

d. uitlokking (penyertaan tindak pidana antara orang yang membujuk atau menggerakkan orang lain sebagai orang yang terbujuk untuk melakukan suatu tindak pidana). ${ }^{23}$

Pertanggungjawaban pidana dalam penyertaan tindak pidana sebagaiamana yang diatur secara umum dalam ketentuan Pasal 55 KUHP adalah masing-masing peserta akan dihukum yang sama beratnya sebagai orang yang melakukan (pelaku) tindak pidana. Dalam hal ini maka antara peserta tindak pidana tidak memenuhi unsur delik (orang yang hanya turut serta melakukan tindak dengan peserta yang memenuhi semua unsur delik akan mendapatkan hukuman yang sama.

Demikian pula bagi peserta yang terbujuk untuk melakukan tindak pidana akan mendapatkan hukuman yang sama beratnya dengan peserta yang telah membujuk untuk melakukan tindak pidana. Pengecualian terdapat pada bentuk doen plegen, di mana pertanggungjawan pidana sebagai pelaku tindak pidana hanya dibebankan kepada peserta tindak pidana yang berkualifikasi sebagai orang yang menyuruh melakukan tindak pidana, karena sebagaimana telah dikemukakan di atas bahwa peserta yang disuruh melakukan tindak pidana adalah orang yang tidak dapat dipertanggungjawabkan secara hukum pidana. Demikian pula dalam penyertaan tindak pidana sebagaimana dirumuskan dalam ketentuan Pasal 56 KUHP yaitu "membantu melakukan tindak pidana" (medeplichtigheid), hukuman bagi peserta tindak pidana sebagai orang membantu lebih ringan dibandingkan

\footnotetext{
${ }^{22}$ Ibid., hal. 319-321.

${ }^{23}$ Ibid., hal. 333-341.
} 
dengan hukuman bagi perserta tindak pidana sebagai orang yang dibantu dalam melakukan tindak pidana.

Dalam hal "penyertaan mutlak perlu" sebagaiana terjadi dalam tindak pidana suap, walaupun pada prinsipnya tindak pidana tersebut juga merupakan penyertaan tindak pidana akan tetapi sebagaimana telah dikemukakan di atas, hukuman bagi masing-masing peserta tidak seperti sebagaimana dirumuskan dalam ketentuan Pasal 55 KUHP, maupun dalam penyertaan mutlak perlu dalam kasus tindak pidana "zinah" (Pasal 284 KUHP).

Tindak pidana suap yang dikategorikan sebagai tindak pidana "korupsi" telah dirumuskan tersendiri dalam UU No.20 Tahun 2001 sebagai perubahan atas UU No 31 Tahun 1999 Tentang Pemberantasan Tindak Pidana Korupsi. Bagi orang yang menyuap maupun yang disuap (yang dalam tulisan ini adalah penumpang dan kondektur KRL/KRD bersangkutan), dirumuskan dalam ketentuan Pasal 5 UU No.20 Tahun 2001 tersebut dengan ancaman pidana penjara masing-masing paling singkat 1 (satu) tahun dan paling lama 5 (lima) tahun dan denda bagi masing-masing peserta paling sedikit sebesar Rp. 50.000.000,- (lima puluh juta rupiah) dan paling banyak sebesar Rp. 250.000.000,- (dua ratus lima puluh juta rupiah).

Ketentuan sebagaimana dikemkakan di atas, berdasarkan "diskresi" Hakim, apabila Hakim menemukan fakta lain dalam tindak pidana korupsi tersebut, misalnya jumlah uang korupsi kurang dari Rp. 5.000.000,- (lima juta rupiah), hakim dapat mempergunakan ketentuan pasal dalam UU yang sama yang lebih bersifat khusus sebagai penerapan dari asas lex specialis derogat legi generali, dengan menerapkan ketentuan sebagaimana dirumuskan dalam Pasal 12 A ayat (2) dari UU No.20 Tahun 2001 yang menyebutkan:

Bagi pelaku tindak pidana korupsi yang nilainya kurang dari Rp. 5.000.000,- (lima juta rupiah) sebagaiamana dimaksud dalam ayat (1), dipidana dengan pidana penjara paling lama 3 (tiga) tahun dan pidana denda paling banyak Rp. 50.000.000,- (lima puluh juta rupah).

Dalam pandangan sepintas sebagaimana telah dikemukakan, para penumpang dalam satu perjalanan "Pulang dan Pergi" (PP) memang hanya memberikan uang kepada kondektur sebesar Rp. 2.000,- (dua ribu rupiah). Akan tetapi apabila perbuatan tersebut dilakukan setiap hari selama penumpang bersangkutan dalam perjalanan PP, kiranya telah dapat dibayangkan perkiraan besarnya jumah uang yang dikeluarkan untuk memberi suap kepada kondektur. Demikian pula bagi kondektur, telah dapat dibayangkan perkiraan besarnya uang 
yang diterima dari sekian banyak penumpang, dikalikan dengan berapa kali ia bertugas dalam satu hari pada kereta yang sama, kemudian dikalikan lagi dengan lamanya kurun waktu tertentu. Dengan demikian maka perbuatan para penumpang dan kondektur bersangkutan setidaknya dapat memenuhi perumusan dalam ketentuan Pasal 12 A ayat (2) UU No.20 Tahun 2001 sebagaimana telah dikemukakan.

\section{Ad.4. Teori mengenai Gabungan Tindak Pidana}

Gabungan tindak pidana (samenloop van strafbare feiten ataupun concursus) terjadi apabila seseorang atau beberapa orang melakukan beberapa tindak pidana dan di antara tindak pidana yang telah dilakukan tersebut belum satupun telah mendapatkan putusan pengadilan. Persidangan bagi beberapa tindak pidana tersebut dilakukan secara bersamaan (sekaligus), baik mengenai penuntutan maupun putusan atas beberapa tindak pidana bersangkutan.

Gabungan tindak pidana terdiri dari berbagai bentuk, dan masing-masing bentuk tindak pidana tersebut memiliki ketentuan tersendiri bagi sistem pemidanaannya, sebagaiaman dirumuskan dalam ketentuan Pasal 63 sampai dengan Pasal 71 KUHP. Adapun berbagai bentuk gabungan tindak pidana dan sistem pemidanaannya tersebut adalah:

1. Gabungan tindak pidana dalam satu perbuatan (eendaadse semenloop ataupun concursus idelais), yang terjadi apabila beberapa tindak pidana tersebut terjadi dalam satu perbuatan, dan dalam satu waktu yang bersamaan (berbarengan). Salah satu contoh dari beberapa tindak pidana yang secara murni termasuk sebagai bentuk gabungan tindak pidana dalam satu perbuatan adalah "perkosaan yang dilakukan di muka umum". Tindak pidana perkosaan tersebut ketentuannya dirumuskan dalam Pasal 285 KUHP, dan tindak pidana terhadap "kesusilaan" (di mana perkosaan termasuk di dalamnya) yang dilakukan di muka umum terdapat ketentuannya sendiri sebagaimana dirumuskan dalam ketentuan Pasal 281 KUHP. Dengan demikian perkosaan yang dilakukan di muka umum tersebut walaupun perbuatan fisik yang dilakukan hanya satu perbuatan, akan tetapi ternyata telah meliputi dua tindak pidana secara bersamaan waktunya, yaitu telah memenuhi ketentuan Pasal 285 KUHP dan sekaligus juga memenuhi ketentuan Pasal 281 KUHP. Adapun mengenai siatem pemidanaan bagi bentruk gabungan tindak pidana dalam satu perbuatan tersebut sebagaimana dirumuskan dalam ketentuan Pasal 63 KUHP adalah berdasarkan sistem "absorpsi murni" (hukuman yang lebih berat menyerap atau menghilangkan hukuam yang lebih ringan), sehingga dalam kasus di atas yang diterapkan adalah hanya hukuman 
sebagaimana ditentukan dalam Pasal 285 KUHP yang mengancam hukuman penjara selama-lamanya 12 (dua belas) tahun. Sementara itu ketentuan Pasal 281 KUHP mengancam hukuman penjara selama-lamanya 2 (dua) tahun 8 (delapan) bulan. Gabungan tindak pidana dalam satu perbuatan dibagi lagi dalam bentuk:

a. Concursus idealis homogenius, yaitu apabila beberapa tindak pidana tersebut adalah sejenis (misalnya seseorang dengan sengaja meledakkan bom pada suatu kerumunan orang, sehingga pada waktu yang bersamaan telah mengakibatkan beberapa orang meninggal;

b. Concursus idealis heterogenius, yaitu apabila beberapa tindak pidana tersebut tidak sejenis, contohnya sebagaimana dikemukakan di atas yaitu perkosaan yang dilakukan di muka umum.

Adapun mengenai sistem pemidanaannya, baik bagi bentuk concursus idealis homogenius maupun bentuk concursus idealis heterogenius adalah sama, yaitu dipergunakan sistem pemidanaan "absopsi murni" (Pasal 63 KUHP). Dalam hal ini walaupun para penumpang dan kondektur bersangkutan telah melakukan beberapa kali tindak pidana dan dari antara tindak pidana tersebut belum satupun tindak pidana yang telah mendapatkan putusan pengadilan, akan tetapi beberapa tindak pidana yang telah dilakukan oleh para pihak bersangkutan tidak termasuk sebagai bentuk eendaadse samenloop ataupun concursus idealis, karena beberapa tindak pidana yang dilakukan oleh para pihak bersangkutan tidak terjadi dalam satu perbuatan dan tidak dilakukan dalam satu waktu yang bersamaan (berbarengan) sebagaimana disyaratkan bagi terpenuhinya perumusan dalam ketentuan Pasal 63 KUHP.

2. Gabungan tindak pidana sebagai perbuatan berlanjut (voortgezette handeling) dengan beberapa persyaratan untuk terjadinya bentuk gabungan tindak pidana tersebut, yaitu:

a. Beberapa tindak pidana itu harus ditimbulkan dari "satu keputusan kehendak", yang baik berdasarkan M.v.T. maupun oleh doktrin selalu dicontohkan dengan penetapan besarnya jumlah uang ataupun barang yang ingin diperoleh sepelaku sebelum ia mulai melakukan serangkaian tindak pidana bersangkutan;

b. Jangka waktu di atara beberapa tindak pidana yang dilakukan itu tidak boleh terlalu lama;

c. Serangkaian atau beberapa tindak pidana yang dilakukan tersebut haruslah sejenis. 
Sementara itu, sistem pemidanaan bagi bentuk voortgezette handeling sebagaiaman dirumuskan dalam ketentuan Pasal 64 KUHP, adalah sama dengan bentuk eendaadse samenloop, yaitu berdasarkan sistem pemidanaan "absorpsi murni". Beberapa tindak pidana yang dilakukan olah para penumpang dan kondektur bersangkutan, telah memenuhi dua persyaratan bagi terbentuknya "gabungan tindak pidana sebagai perbuatan berlanjut" (voortgezette handeling), yaitu pertma: jangka waktu di antara beberapa tindak pidana yang dilakukan itu tidak terlalu lama, di mana dalam hal ini dapat dikatakan bahwa tindak pidana itu dilakukan hampir pada sertiap hari. Kedua: beberapa tindak pidana yang dilakukan oleh para pihak bersangkutan adalah sejenis, yaitu tindak pidana "suap". Akan tetapi serangkaian tindak pidana yang dilakukan para pihak bersangkutan tidak termasuk dalam bentuk voortgezette handeling ini, karena serangkaian tindak pidana tersebut tidak ditimbulkan dari "satu keputusan kehendak", di mana para pihak bersangkutan tidak pernah menetapkan terlebih dahulu besarnya jumlah uang yang akan diberikan ataupun yang akan diterima. Mereka akan selalu memanfaatkan kesempatan yang ada untuk melakukan tindak pidana "suap" tersebut, tanpa tergantung atau tanpa dibatasi pada besarnya jumlah uang yang akan diberikan ataupun yang akan diterima oleh masing-masing para pihak pihak bersangkutan.

3. Gabungan tindak pidana dalam beberapa perbuatan (meerdaadse semanloop ataupun concursus realis), yang terjadi apabila seangkaian tindak pidana yang dilakukan itu tidak terjadi dalam satu waktu yang bersamaan. Tidak dibatasi pula oleh persyaratan bahwa serangkaian tindak pidana itu harus sejenis, sehingga serangkaian tindak pidana yang tidak terjadi dalam satu waktu yang bersamaan tersebut dapat terdiri dari serangkaian tindak pidana yang sejenis (concursus realis homogenius), yaitu misalnya seseorang melakukan beberapa kali tindak pidana "pencurian". Dapat pula terjadi serangkaian tindak pidana tersebut terdiri dari beberapa tindak pidana yang tidak sejenis (concursus realis heterogenius), misalnya seseorang setelah melakukan tindak pidana "pencurian", kemudian dalam waktu yang berbeda ia melakukan tindak pidana "penganiayaan", dalam waktu berikutnya ia melakukan tindak pidana "perkosaan" dan dalam waktu berkiutnya mungkin melakukan tindak pidana lainnya lagi. Dalam bentuk meerdaase samenloop atau concursus realis tersebut juga tidak dibatasi olah persyaratan bahwa serangkaian tindak pidana bersangkutanharus saling terkait antara tindak pidana yang satu dengan tindak pidana yang lainnya, sehingga dalam bentuk 
meerdaadse sameloop atau concursus realis dapat terjadi dari serangkaian tindak pidana yang masing-masing merupakan tindak pidana yang berdiri sendiri. Ketentuan mengenai bentuk meerdaadse samenloop atau concursus realis tersebut terdapat dalam perumusan Pasal 65 KUHP, dengan sistem pemidanaan "absorpsi yang diperberat", di mana dalam ketentuan Pasal 65 ayat (2) KUHP, hukuman yang dapat dijatuhkan adalah hukuman terberat di antara serangkaian tindak pidana bersangkutan, dan dapat diperberat dengan ditambah 1/3 (satu per tiga) dari hukuman terberat tersebut. Apabila dicermati kembali mengenai serangkaian tindak pidana yang dilakukan oleh para penumpang dan kondektur bersangkutan, maka serangkaian tindak pidana tersebut jelas termasuk bentuk gabungan tindak pidana dalam beberapa perbuatan (meerdaadse sameloop ataupun concursus realis), khususnya lagi dalam bentuk "gabungan tindak pidana sejenis dalam beberapa perbuatan" (concursus realis homogenius).

\section{Penutup}

Walaupun telah nyata secara terang benderang bahwa serangkaian tindak pidana yang dilakukan oleh para penumpang dan kondektur KRL/KRD di wilayah JABODETABEK tersebut telah memenuhi semua teori sebagaimana dikemukakan di atas, sehingga sebenarnya para pelaku bersangkutan telah dapat dipertanggung jawabkan secara hukum pidana, akan tetapi perlu diingat mengenai terdapatnya semboyan dalam hukum pidana, yaitu bahwa pelaksanaan hukum pidana merupakan "senjata pamungkas" (ultimum remedium). Pelaksanaan hukum pidana pada umumnya akan mendatangkan nestapa, baik fisik, moril, maupun materil, bagi mereka yang dipersalahkan, maka dengan demikian apabila masih terdapat upaya lain sebelum dilaksanakannya ketentuan hukum pidana, upaya lain tersebut secara maksimal harus dilakukan terlebih dahulu.

Dalam hal ini walaupun agak terlambat, akan tetapi pihak PT. KAI telah terlihat terdapatnya upaya untuk mencegah makin meningkatnya perilaku para penumpang KRL/KRD di wilayah JABODETABEK yang enggan untuk membeli tiket sebelum menaiki kereta. Usaha yang kiranya dapat dikatakan memiliki dua fungsi sekaligus, adalah tindakan PT. KAI dalam membangun "jeruji besi" yang dipasang di atas teras pada hampir setiap stasiun kereta yang disinggahi KRL/KRD bersangkutan.

Dua fungsi dari pemasangan jeruji besi tersebut tentunya dimaksudkan untuk: (a) mencegah para penumpang agar tidak dapat naik ke atas atap kereta demi 
keamanan para penumpang itu sendiri; (b) karena ia tidak dapat naik ke atas gerbong kereta dengan merasa bebas tanpa memiliki tiket, maka diharapkan semua penumpang akan masuk ke dalam gerbong kereta dengan tentunya membeli tiket terlebih dahulu.

Ternyata sebagaimana terlihat dalam pemandangan sehari-hari, para penumpang KRL/KRD di wilayah JABODETABEK yang naik ke atas gerbong kereta masih sangat banyak. Hal ini tentunya disebabkan tidak seimbangnya jumlah pengguna jasa $\mathrm{KRL} / \mathrm{KRD}$ dengan jumlah $\mathrm{KRL} / \mathrm{KRD}$ yang tersedia di wilayah JABODETABEK, sehingga tidak semua penumpang dapat tertampung dalam gerbong kereta bersangkutan (khususnya pada saat orang berangkat bekerja pada pagi hari dan orang pulang dari bekerja pada sore hinggan malam hari. Di samping penyebab tersebut, penyebab lainnya adalah mengenai sikap dan perilaku sebahagian penumpang yang memang sengaja ingin melakukan perbuatan melawan hukum.

Merasa bahwa upaya pencegahan sebagaimana yang telah dilakukan PT. KAI itu kurang membawa hasil yang maksimal, maka dimulai dari beberapa waktu lalu, pihak PT. KAI menempatkan beberapa petugas di hampir setiap stasiun kereta KRL/KRD untuk memeriksa setiap calon penumpang kereta bersangkutan mengenai kepemilikan tiket dari para calon penumpang tersebut.

Berbagai upaya PT. KAI untuk mencegah kerugian yang makin besar tersebut kiranya patut dihargai, akan tetapi upaya tersebut diharapkan dilakukan secara permanen, dan pengelolaannya benar-benar dilakukan secara professional, sehingga dalam upaya tersebut akan diperoleh lebih kepada "kemanfaatan" ataupun "keuntungan" dari pada "kemubaziran" atau bahkan "kerugian" yang makin besar. 


\section{Daftar Pustaka}

Agustina, Rosa. Perbuatan Melawan Hukum, Cetakan 1, Jakarta: Program Pascasarjana FH-UI, 2003.

Alwi, Hasan. dkk., Kamus Besar Bahasa Indonesia, Edisi III, Cetakan 1, Jakarta; Balai Pustaka, 2001.

Emong Sapardjaja, Komariah. Ajaran Sifat Melawan Hukum Materiel Dalam Hukum Pidana Indonesia, Cetakan 1, Bandung: Alumni, 2002.

Lamintang, P.A.F. dan D. Simon, Kitab Pelajaran Hukum Pidana (Leerboek het Nedelandches Strafrecht), Cetakan 1, Bandung: Pionir Jaya, 1992.

Loqman, Loebby H. Percobaan, Penyertaan Dan Gabungan Tindak Pidana, Cetakan 1, Jakarta: Universitas Tarumanegara, 1996.

Moch. Anwar, H.A.K. (Dading), Hukum Pidana Bagian Khusus (KUHP Buku II) Jilid 1, Cetakan 4, Bandung: Alumni, 1986.

Seno Adji, Indriyanto. Korupsi Kebijakan Aparatur Negara \& Hukum Pidana, Cetakan 2, Jakarta: Diadit Media, 2007.

Prodjodikoro, Wirjono. Asas-Asas Hukum Pidana di Indonesia, Cetakan 2, Bandung: Eresco, 1979.

Sianturi, S.R. Tindak Pidana Di KUHP Berikut Uraiannya, Cetakan 2, Jakarta: Alumni AHAEM-PETEHAEM, 1989.

Sudarsono. Kamus Hukum, Edisi Baru, Cetakan 5, Jakarta: Rineka Cipta, 2007.

Sugandhi, R. KUHP Dan Penjelasannya, Surabaya: Usaha Nasional, 1980.

Soesilo, R. KUHP Lengkap Dengan Komentar Pasal Demi Pasal, Bogor: Politeia, 1980.

Wowasito, S. Kamus Umum Belanda-Indonesia, Jakarta: Ichtiar Baru-Van Hoeve, 1981. 